\title{
Organization Intelligence and Bureaucracy Reform at Public Organization in Indonesia
}

\author{
Ismiyarto, $\mathrm{SH}, \mathrm{M} \cdot \mathrm{Si}^{1}$ \\ ${ }^{1}$ State Governmental Institution (Ipdn) Jakarta College, Indonesia \\ Correspondence: Ismiyarto, State Governmental Institution (Ipdn) Jakarta College, Indonesia. E-mail: \\ anto200708@gmail.com
}

Received: December 22, 2017

Accepted: January 2, 2018

Online Published: January 19, 2018

doi:10.5539/mas.v12n2p93

URL: https://doi.org/10.5539/mas.v12n2p93

\begin{abstract}
Organization intelligence and bureaucracy reform are important part of public administration. It is values and credibility agreed (the shared value and beliefs) which is learnt, applied continuity becoming main characteristic as guidance for organization members have behaviors, concurrently increasing its performance. It achieved through bureaucracy reform. In taking an easy way of explaining and more operational bureaucracy reform, thus government proclaims nine programs of acceleration bureaucracy reform. Illustrating paradigm changing, organization structure, management, policy, framework term and human resource intelligence work that are guided to budget conserving, rectifying public service quality, stimulating government performance mechanism efficiently and effectively. Tidying up of organization intelligence by one of its dimension is the difficult act into bureaucracy reform implementation while compared with intelligence process, structure and procedure. This research is done by applying descriptive methods of qualitative analysis include in a case study research. The result shows that one of public organization has implemented integrity values, professional and accountable in an internal area of nine programs on bureaucracy reform acceleration. There are nineteen activities becoming part of following up of these programs that totally reflect on an organization intelligence dimension, the suggestion of this model and able to overcome obstacle factor. In accelerating realize apparatus whose have integrity, professional and accountable need a lot of activities as following up of survey result of nine programs on bureaucracy reform acceleration program both of internal or external areas cooperate with independent institution.
\end{abstract}

Keywords: Indonesia, organization intelligence, bureaucracy reform, public administration, nine programs, bureaucracy reform acceleration and organization structure

\section{Introduction}

Today the dynamic and civilization moving on bureaucracy concept focuses on giving service fulfillment to society necessities. This moving as far as parallel with public administration paradigm on implementation government functions aims to creating good governances. In realizing society prosperity and its justice become Nation obligation daily, in order to be created government. The government as State personification is efforts to implement missions and realize their goal maximally. Bureaucracy as government instrument personification takes a role into government bureaucracy of career position organizer. The administration and government bureaucracy very depend on its State apparatus performance; there isn't more important thing into modern time than administration. The continuity of government moral creates its civilization continuity in modern time will be very depend on State apparatus skill within developing and improving a philosophy and bureaucracy administration system which is able to solve modern societies problems.

The statement from Bearnard and Lepawsky who having oldest age, now these are still acknowledged and referred its accuracy especially from "public administration perspective aiming to reach State goal by collaborating various sectors include government sector, private and public society through humaneness policy and having justice" (Sailiwa Wirman Syafri, 2012:34). Government bureaucracy classified into and centre and regional government bureaucracies together with their apparatus, supporting the function of executive capability such as President as Head of State and Head of Government into realizing executive function daily. Therefore bureaucracy role is very strategic. This condition is suitable with what was stated by Thoha (1992:62 into Masana Sembiring), that: bureaucracy role becomes bringing up around societies because they have developed 
politics controllers who has been delegated planning managements and policy implementation in bureaucracy even though hanging up in a bureaucracy infrastructure. Therefore the strategic position and professional skill on its function, together with planning mechanism and policy implementation are very connected, thus bureaucracy role in public policy very deciding.

The problem today relates to what does bureaucracy in Indonesia has been able in implementing government missions and development effectively and efficiently? The nation historical as long as 70 years hasn't able realize bureaucracy figure expected, especially into public service organized by government bureaucracy. Based on Siagian (1996:39) there were a lot of problems usually becoming public complaint related to government bureaucracy service by apparatus usually showed exasperated actions such as: (1) slowing down the authorization completing process; (2) looking for various reasons including incomplete document component, the lateness submission and other relates reasons; (3) having another activity task; (4) complex to be called; (5) continually slowing down by words "in a process". Various exasperated actions impact on the higher budget economy, it based on a survey in 2013 of Corruption Perception Index by Transparancy International showed that Indonesia were on at 114 position, Thailand at 11, while Singapore at 5 and New Zealand at first position. Based on the result of Efficiency of Bureaucracy Scores 2012 Asian Countries, Singapore got 2,25 score; Indonesia got 8,37 score while India got 9,21.

Various critiques about bureaucracy system inefficiently in Indonesia, the highest quantity and ungraceful have been frequently stated directly which are a deterioration in government bureaucracy system in Indonesia (Thoha, 2009:11). Moreover bureaucracy in Indonesia hasn't been able implemented government regular task and development tasks effectively and efficiently. Organization intelligence is related to bureaucracy reform, both of theoretical problem or empirical problem, there are classification and similarity that is able to be drawn a conclusion like on this paragraph, while there is a main factor to stimulate the bureaucracy reform successful such as: first, politic commitment and leadership; second, authorities coalition and co-partnership; third, the clearness trajectory changing; forth, reform the reformers; fifth, comprehensive roadmap and gradual implementation (Eko Prasojo, 2014). Bureaucracy reform isn't part of instant task and isn't easy, need a long process and long period. While it needs grand design and road map clearly. Then need to be arranged agenda setting clearly about focus, locus and strategy rank constantly (Thoha, 2007:97).

\section{Previous Researches}

Government bureaucracy has to able implementing task effectively and efficiently, it is needed transformation and improvement like containing in the bureaucracy reform program. In this implementation of bureaucracy reform one of aspect need to be organized is organization intelligence. Bureaucracy reform is meant as an effort in implementing main transformations into a bureaucracy system aimed to transform structure, behavior, and existence and obsolete behavior (Khan, into Arief Idris 2013:136). The insight parallel with Quah that define reform as "a process aim to transform process and public bureaucracy procedure so is action together with bureaucracy habit to reach bureaucracy effectiveness and national development goal". Then from Samonte that confer similarity insight about reform "as transformations or innovations by applying premeditation and adoption to create administration system as institution or agent more effectively aim to social transformation, as a good instrument to convey political similarity, social, and economy changing. All of them are stated into development acceleration and nation development (Ibid., 136). This definition come from various specialists about this reform above relate to four aspects: first, reformation relates to innovation and transformation; second, reformation successful need a transformation systematically and broadly, this transformation has to be implemented carefully and planned; third, reformation goal is reaching efficiency and effectiveness; fourth, reformation has to be able defending transformations. Therefore, reformation framework is unlimited onto process and procedure, but it relates to transformation of structure level and behavior. This meant that it relates to problems contiguous with authority.

Then bureaucracy meaning taken from Indonesian Master Dictionary known as KBBI, bureaucracy is defined as follows: first, government system that is performed government apparatus because they has been taken a principle hierarchy and position level; second, working ways or its structure are often slow, thus bases on rule arrangement (custom and other) unstructured and others. Mustafa Delly (2013:1) stated: Bureaucracy meant based on definition stated by various experts were a controlling system in organization planned based on rational rules, systematic and aiming to coordinate and guide working individual activities into administration completion tasks highly (stated from Blau \& Meyer, 1971; Coser \& Rosenberg, 1976; Mouzelis, into Setiawan, 1998). Then Blau into Sinambela (2006:70), stated that "bureaucracy is organization aimed to maximize administration efficiently". 
Bureaucracy meaning bases on definitions stated by various experts are a controlling system in organization arranged bases on rational rules, systematic and aiming to coordinate so does guiding apparatus working activities within completing administration tasks highly (summarized from Blau \& Meyer, 1971; Coser \& Rosenberg, 1976; Mouzelis, dalam Setiawan, 1998). Then Blau dalam Sinambela (2006:70) stated that "bureaucracy was an organization aimed to maximize administration efficiency". Based on understanding of reform and bureaucracy stated above, thus bureaucracy reform can be understood as follows: First, transforming or rectifying government system condition in order the implementation of government administration able to be better; Second, a part effort of basis arrangement that is hoped impact on transformation system and structure. System relates to relationship of an element mutually influencing and relating to create a totality, structure relates to rules arranged regularly and systematically; Third, illustrating paradigm transformation together with organization structure transformation, management, policy, opinion and human resource intelligence addressed to economize State budget, rectifying public service quality and stimulating government performance mechanism which was more efficiency and effectively (Pollit \& Bockaert, 2000: Hughes, 2003: Denhardt \& Denhardt, 2003, into Keban, 2010:15); Fourth, State apparatus development includes all of refining efforts, guidance and State apparatus disciplining in order able to implement their task, role and function efficiency, effectively and productive along with avoiding from blameworthy act (Rewansyah, 2010:116).

The urgency of bureaucracy reform stated by various experts above, thus it is hoped next bureaucracy will be able implementing task effectively and efficiency together with transformation and restoration through bureaucracy reform policy. Necessities existence in transformation implementation and bureaucracy renewal depends on necessity and national leader commitment, starting from President to regional heads have to implement this renewal. Reformation apparently impossible performance effectively if there isn't on government controlling of this State that refers to President. The national strategy of environmental transformation into bureaucracy absolutely needs a plan and State apparatus renewal or government. The transformation starting from 1998, by started a monetary crisis and transformation of national political system along with started bureaucracy reform renewal. The factor of environmental transformation is strategic globally require done renewing State apparatus/government that are implemented into bureaucracy reform area. This transformation globally is transformation process that should be reconciled. These are stated including, decentralization assertion, democracy, autonomy, accountability, transparency, law constructing. They become forceful power in creating management transformation and government bureaucracy. These transformation fields have been done State overseas who desire good governance obviously. These transformations appear along with paradigm transformation occurring into government management paradigm. That is hoped will able to stimulate presence of government bureaucracy reform. A bureaucracy is done by accommodating practical and technology information development into government. E-government applying into government bureaucracy is hoped able to give service for society and able to be organized better.

Rewansyah (2009:134), writing down in his analysis, explained that bureaucracy reform need to be implemented, it was based on various reasons as follows: first, the transformation of paradigm system that was otoriterian-centralize to the democracy-decentralize government system; second, the condition of nation objective and government bureaucracy that day. While the condition of nation objective existence today signed by as follows: 1) the rank of corruption perception in Indonesia is the higher in Asia; 2) the highest of underprivileged community $(37,17$ millions or $16,6 \%) ; 3)$ the unemployment amount $(10,55$ millions or 9,8\%); 4) the lack of investment desire and 5) The Millennium Target of Development Goals (PBB Declaration Number 55 in 2000) where every country of PBB members should decrease underprivileged community and unemployment amount $50 \%$ in the last of 2015 .

While Eko Prasojo (2012:10) stated that at least there were twelve programs what able to become leverage into bureaucracy reform acceleration, including: 1 ) the assessment of ministry or organization; 2 ) recruitment system basically on technology information; 3) the promotion system done transparently; 4) public service monitoring system; 5) public service complaining system nationally; 6) human resource management system of government; 7) reform the reformers; 8) public campaign for bureaucracy reform; 9) competency test for civil servant (talents mapping) ; 10) e-integrated competence based human resource system; 11) the development of integrity zone access to unattached corruption area, and 12) the development of independent assessment system of bureaucracy reform implementation (PMPRB) online. The important of transformation urgency into bureaucracy reform were also categorized by Keban (2009:251). Keban explained that there were fourth aspects why bureaucracy reform need to be implemented, namely "First, stimulating bureaucracy vision; Second, creating bureaucracy creatures; Third, developing bureaucracy system, and Fourth, developing bureaucracy environment". Afterwards, into developing bureaucracy system Keban stated that organization intelligence straightening relate to pattern source 
from value and norms along with belief who able to help organization members surely would understand how did organization work, and how did value and belief influence their behavior in organization. It had been improved bureaucracy performance because it very influenced into bureaucracy behavior (Ibid, 2008:255).

Sembiring (2012:73) gave an opinion that there were fifth dimensions of organization intelligence, namely: 1) Faith and Devotion; 2) Professionalism; 3) Community Orientation; 4) Performance Orientation; and 5) Employee Prosperity Orientation. The understanding of organization intelligence was through various ways, there was stated model by analyzing various steps, and there were also presented as a process (Wibowo, 2012:199). The researcher interprets that organization intelligence model is a pattern consistently relates to values and belief agreed (the shared value and beliefs) learnt, applied continuity who become main characteristic regarding Integrity Values, Professionalism and Accountable thus conferring sense as well as guidance for dignitary and public organization staff in attitude and action. The processes of appearance, socialization, internalization and value applying include onto model of organization intelligence development.

\section{Discussion}

Bases on background and theory stated by various experts, while it can be presented a discussion result as follows:

\subsection{Organization Intelligence into Nine Programs of Bureaucracy Reform Acceleration at a one of Public Organization}

\subsubsection{Professionalism Dimension}

a. Professionalism dimension is related to organization structure arrangement, organization structure flexibility, this reforming is realized by ministry rule transformation, turned with main task and each function at working area. This rule is implemented by dynamic professionally, if the assessment bases on subjectivity while professionalism is difficult to be applied. Organization structure in a line form, which meant structure is simple, relationship arrangement between each component part and position in an organization. This structure existence today involve simplify through reducing various working area at echelon I. The organization structure simplifies and clearness will impact on efficiency. Component and organization proponent position are able to be explained clearly while it will explain each task among deputy. Organization structure also illustrates activities namely coordination and authorities owned by working area. Individual and employee that involve into organization able to influence organization structure, it is because of previous explanation discussed at echelon I level, the precede concept discussed previously by fellow dignitaries and employee at each echelon I addressed. This activity shows that ability and individual thinking ways along with their necessities in joining influence authority and relationship among working unit then it will able to influence organization structure.

b. Professionalism dimension is related to amount arrangement and civil servant distribution. There isn't arrangement noted about this case, although it is claimed that amount arrangement and civil servant distribution stable claimed, meant employee amount work at public organization addressed is stable amount relatively, because retire employee will be replaced by employee who getting promotion job. They also face position rotation or mutation both of echelon I or echelon II every one or two years, it impacts on human resource amount stabile.

c. Professionalism dimension is related to selection of civil servant system transparency, starting from selection admission to announcement of new employee honored done transparency meant that all of participant able to check from website, including complaint of civil servant recruitment, thus there isn't "nepotism" process, then it will impact professionalism around new employee recruited because they have been selecting from excellent resource. Professionalism dimension relates to civil servant promotion transparently, aimed to fulfill echelon I and echelon II positions by all of candidates come from various public organizations. The implementation obstacle doesn't find significantly, while psychologically sensed by public organization dignities, for example: they have been long period on echelon III doesn't automatically on echelon II, like that on echelon II, they are senior but doesn't automatically on echelon I position and they have to compete strictly through competition series from outside of public organization.

d. Professionalism dimension is related to civil servant professionalism, they are required to implement role and function base on dependable competency and continuity increasing their skills and liabilities. Implementing talent mapping, capacity building, the technical of educational training or functional training are hoped able to trainee civil servant in upgrading their knowledge, attitude and behavior. But for technical of educational training and functional training implementation still felt not maximal.

Bases on this case above, arranged minor proposition as follows: 
Minor proportion 1: by creating accurate and standard organizations; human resource amount is still stabile, civil servant requirements is reliable, objective, transparency; the leader quality comes from both of internal or external; skill, proficient, and experience which is realized into daily tasks behavior impact on strengthening of professionalism dimension.

\subsubsection{Societies Orientation Dimension}

a. Societies orientation dimension is related to public service advantaging. In its activity usually support bureaucracy reform acceleration through public service advantaging by determined public service standard at public organization, in acknowledging as far as of service thus implemented survey of society satisfaction onto service consultation related to policy has been issued. Bases on survey result shows advantaging in this category from time to time, while it still need an improvement from service time substance. There is a behavior and staff comportment transition such as friendlier when they receive a guest, both of in front office or dignitary so is staff in every working unit.

b. Societies orientation dimension is related to advantaging transparency and civil servant accountability. Since begun a bureaucracy reform that have been applied quick wins presented onto information system applying, dominantly related to complaint handling of various policies issued and its handling electronically. Because every policy consist of rules that have to be supported by all of working unit echelon I, before the policy has been issued then it need to be coordinated in this policy arrangement. It will impact on the transition of attitude transition and behavior especially into coordination of policy arrangement. The other impact of transparency advantaging program and civil servant accountability from integrity values are dignitary or staffs don't be permitted receive a gift or memento from guest calling on.

Bases on this case explained above, arranged minor proposition as follows:

Minor Proposition 2: By arranging public service standard and survey executed of communities satisfaction: policy arrangement coordination among working unit echelon I; and integrity advantaging is doesn't receive a gift or memento relate to their task, realized into attitude and daily task behavior that will able to force societies orientation dimension.

\subsubsection{Performance Orientation Dimension}

Performance orientation dimension is related to E-Gov advantaging, this application applies electronic system. Application often applied relate to documentation application of budget realization on government duty includes letter assignment, letter institution duty, budget application and detail of outcome list. That impact of applying this system is all of assignment become regularly and secure. It is meant that liabilities related to budget is suitable with Standard Operating Procedure, thus it couldn't found when it established inspecting. The other impact is budget economizing, although program planning become every authority of working echelon I, thus budget consuming is controlled by KPA (Budget Consuming Authority) or internal controller. Then the E-gov applying able to economize budget because by implemented procedure restoration of lettering process through Short Message Service center utilizing and e-mail, it is very simple and doesn't need paper for printing out and copy, by utilizing SMS centre in a year able to economize budget amount IDR 1,2 billion.

Performance orientation dimension is related to efficiency of facility utilizing and infrastructure of civil servant. Base on evaluation result side of performance accountability indicates value advantaging for evaluation result of performance accountability. It impact on remuneration increasing, facility and infrastructure also indicate upgrading such as : ATM facilities, canteen, charger box, health care facility for staff, guest parking area in front of building, special complaint room and consultant to all guest, bathroom, and cleanness toilet so is tabernacle. These all will impact on performance increasing and working environment condition is more comfortable, it because an attitude and behavior or caring aim for better performance from leader to dignitary and staff in a working unit.

Bases on the case above, arranged minor proposition as follows:

Minor Proposition 3: By accomplishing job bases on Standard Operating Procedure; impact on Budget economizing; performance increasing; and working condition is feel more comfortable, realized onto attitude and daily task behavior will be able to strengthen performance orientation dimension.

\subsubsection{Staff Prosperities Orientation Dimension}

It is related to prosperities rising of civil servant. This prosperities is not only determined from financial field, for example a remuneration rising from $39 \%$ to $75 \%$ but also into non financial field such as medical service or general check up, positioning rising automatically without dignitary or staff has to fulfill administrative 
requirement so are retired period facility, training on pre-retired period, entrepreneurship and furloughed or holiday. But there is a complaint about salary and subsidy sent to staff and dignitaries have a significant distinction.

Bases on the case above, arranged minor proposition as follows:

Minor Proposition 4: By a rising remuneration amount; clinic availability and medical service or general check up; positioning rising automatically; the dignitary or staff easiness nearly retired period; and sent furlough authority; that is realized into attitude and daily task behavior will be able to strengthen staff prosperities orientation dimension.

Attitude and staff or dignitary behavior because of belief, norms, and values along onto activities aimed to accelerate nine programs of bureaucracy reform acceleration which is reflecting from these fourth dimensions (professionalism, society orientation, performance orientation, and staff prosperities orientation). Belief and devotion of orientation dimensions take a basic role into these fourth dimensions, namely better model of leader that able to convince their staff to respect and obey so is devotion to god based on their belief, respecting each other staff, reciprocal assistance, integrities upholding, obey to staff ethic codes. The activities implementation is an explanation of nine programs of internal bureaucracy reform at one of public organization done by five working group, every group implement from four to eleven activities, which meant every group has been classified into their working group. There are five working groups who implement a lot of activities to support nine programs of bureaucracy reform acceleration, it improves classifying task in order every groups have to liabilities in their successful task.

Bases on these cases above, the researcher interprets organization intelligence onto nine programs of bureaucracy reform acceleration at public organization, By comparing previous strategy done into bureaucracy reform includes transformation not only bases on facilities and infrastructure or physically, but also a transformation culture improved by attitude and behavior from dignitary of staff internally. It is also supported by index result survey from research done by outside independent institution focuses on organization intelligence which improve performance advantaging bases on this dimension onto nine programs of bureaucracy reform acceleration. It is conforming to research done by researcher, such as found nineteen (19) activities as nine programs continuity of bureaucracy reform acceleration program. From these nineteen activities, actually they haven't been based on policy called as rules, for example onto advantaging program of civil servant prosperity, including positioning rise automatically without attaching another terms.

To easiness of organization intelligence understanding into nine programs of bureaucracy reform at one of public organization able to be described as follows:

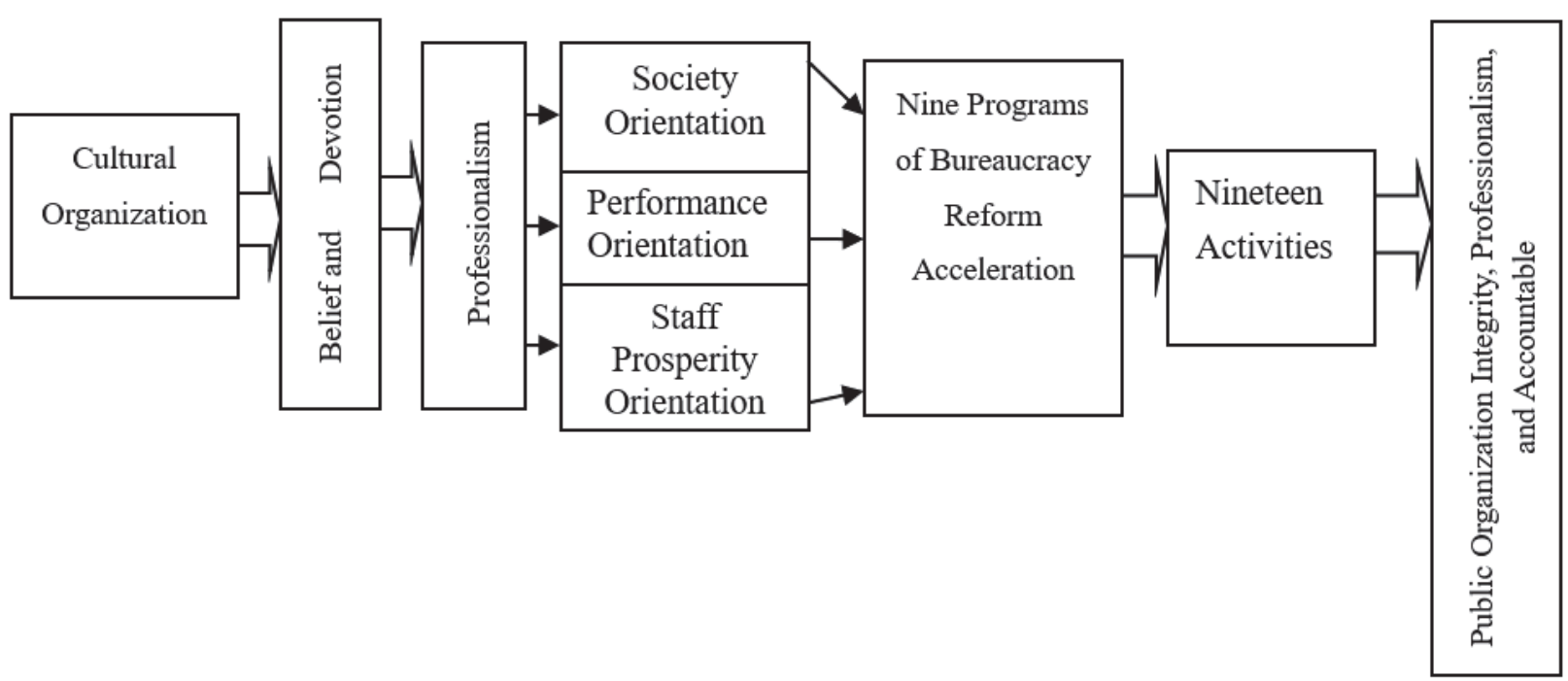

Figure 1. Organization Intelligence and Bureaucracy Reform at Public Organization 
Bases on the case above, arranged minor proposition as follows:

Minor Proposition 5: By belief and devotion dimensions that basically these four dimensions namely Professionalism, Societies Orientation, Performance Orientation and Staff Prosperity Orientation, will able to "accelerating" nine programs of bureaucracy reform acceleration supported by nine classifying activities realized into daily task behavior will strengthening public organization apparatus that are integrity, professional, and accountable.

\subsection{Organization Intelligence Model into Nine Programs of Bureaucracy Reform Acceleration at One of Public Organization}

3.2.1 Organization Intelligence Model into Nine Programs of Bureaucracy Reform Acceleration at One of Public Organization (Existing)

This understanding is systematic pattern relates to values and belief agreed (the shared value and belief) learnt, applied continuity that become main characteristic about appearance process, formatting, socialization, internalization and applying Integrity values, professional and Accountable in order beneficial and guidance for dignitary together with staff in take an action and behavior.

Following is presented understanding of each process namely appearance process, formatting, socialization, internalization and applying Integrity values, professional and Accountable.

First, Appearance Process and Integrity Values of Organization Intelligence

a. Appearance process and formatting excellent values include Integrity, Professional, and Accountable through long process started from leader commitment in developing excellent intelligence as important way onto bureaucracy reform implementation.

b. This process continues until stall implementer level, moreover the security and cleaning service, in order agreed together.

c. All of dignitaries echelon I, echelon II and Internal Bureaucracy Reform Team are hoped becoming role model into IPA implementation for all staff.

d. In every working unit of dignitary echelon III becomes a transformation agent to stimulate transformation acceleration process in every working unit.

e. Thus excellent intelligence values of IPA aimed able to be applied by every dignitary and staff in supporting realization vision of fair apparatus, competent and providing service, while it is issued rules about ethic code staff.

Second, Socialization and Internalization

a. Socialization to all dignitaries or staffs done once a month.

b. Socialization activities are done through reform corner meeting.

c. Every meeting invites speaker outside followed by all dignitaries and staffs.

d. Leaflet separating and banner positioning at strategic place especially in lobby, beside the lift and beside entrance room.

e. Internalization activities of organization intelligence values to all dignitaries or staff in a working group area directly relates to this activity.

f. The Internalization of excellent intelligence value (powerful and adaptive) is done continuity such as created integrity group followed by internalization dignitaries and staffs in all working unit.

g. Internalization followed up by issued a handbill about advantaging of staff integrity relates to gift offering, that meant suggested doesn't send gift into all stuff both of dignitary or staff.

h. Issued rules about ethic code staff which is obligating staff to priority good behavior, discipline, serving, competent, able to finish work on time and liable task bases on processing sides and the best result.

i. For breaking this ethic code, there is a staff discharged from a job, includes coming back to their first institution.

Third, applying of organization intelligent values

a. In order of implementation or applying of IPA values, created role model and transformation agent hoped able to initiate various transformations in every working unit.

b. The applying of IPA excellent intelligence values arranged into a decision. 
c. Determined tens of transformation agent people as pioneer of implementation of internal bureaucracy reform.

d. The real planning act reflecting attitude or behavior of values integrity realization, such as: 1) gratification prohibition for dignitary or staff; 2) manufacturing a banner (disallowed receiving gift or gratification) at strategic place; 3) positioning "gifts" coming from foreigner representatively; 4) refusing to sign a SPPD/ consignment/ other activities that aren't suitable with assigning task (fictive); 5) refusing to create report and document relate to policy and 6) refusing all facilities prepared by other public organization when visiting other region.

Bases on the cases above, here is illustrated a organization intelligence model into nine programs of bureaucracy reform acceleration at a public organization (Existing), as follows:

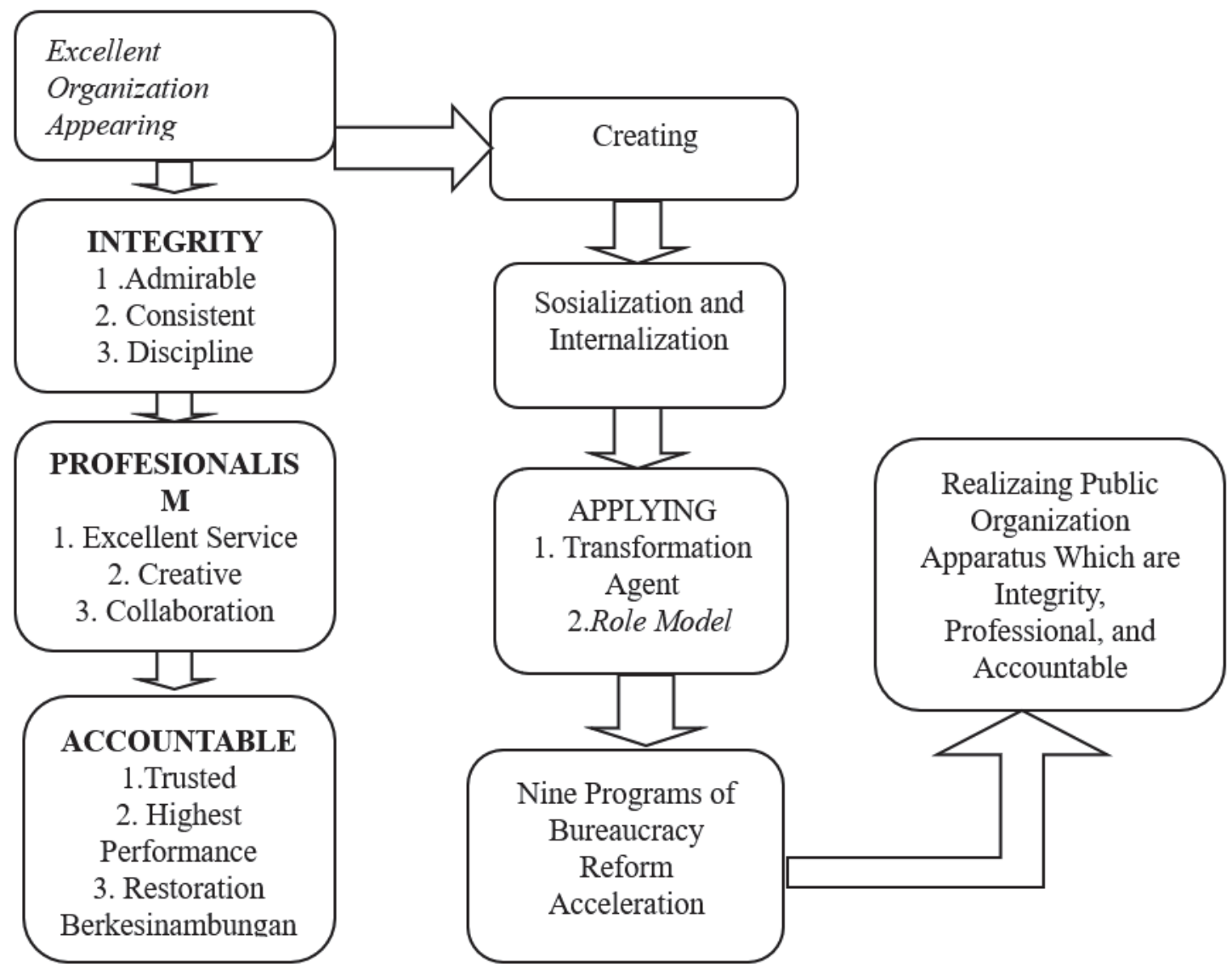

Figure 2. Organization Intelligence Model and Bureaucracy Reform at Public Organization (Existing)

Source: Performance Accountability Report in 2013 (adapting) and research result.

Minor Proposition 6: Organization Intelligence model is systematic pattern relate to values and belief agreed (the shared value and beliefs) learnt, applied continuity that become main characteristic about rising process, creating, socialization, internalization and applying values of Integrity, Professional and accountable into nine programs of bureaucracy reform acceleration will realize public organization apparatus which is integrity, professional and accountable.

\subsection{Organization Intelligence Model into Nine Programs of Bureaucracy Reform Acceleration Programs (Recommendation)}

The researcher analysis result of organization intelligence model into nine programs of bureaucracy reform acceleration (recommendation) as follows:

a. IPA values at one of public organization is still relevant, but in future it will be conform by external development and the next government program, because of every five years of government era is always newest. 
b. Socialization activities and IPA values internalization while it will be able increased especially for new staff.

c. The IPA values applying, the training is more intensive because dignitary or staffs become a role model members and transformation agent partially going through retires time.

d. The benefit training is more intensive for updating because the role model act and transformation agent are very determining the successful applying of IPA values in advantaging performance relate to nine programs of bureaucracy reform acceleration.

e. For more concrete in daily task need to be explained into activities that form explanation of nine programs of bureaucracy reform acceleration, researcher find there are nineteen activities, surely for the next research will be more find activities found, because it has been published various constitutions as bureaucracy reform pillar.

f. Constitutions as bureaucracy reform pillar, namely: Regulation Law Number 39 in 2008 about Ministry State and various implementation rules; Regulation Law Number 25 in 2009 about public service and its rules; Regulation Law Number 5 in 2014 about civil servant apparatus and its rules and Regulation Law number 30 in 2014 about government administration.

g. Activities implementation for more consistently as following up of these fourth bureaucracy reform pillars addressed, concretely in space for formatting implementation rule such as government, president rules until ministry rule for suitable with mutant material arranged into Regulation law as bureaucracy reform pillar.

Bases on the explanation above, researcher suggests organization intelligence model into nine programs of bureaucracy reform acceleration at Ministry for Administrative and Bureaucracy Reform Apparatus as follows:

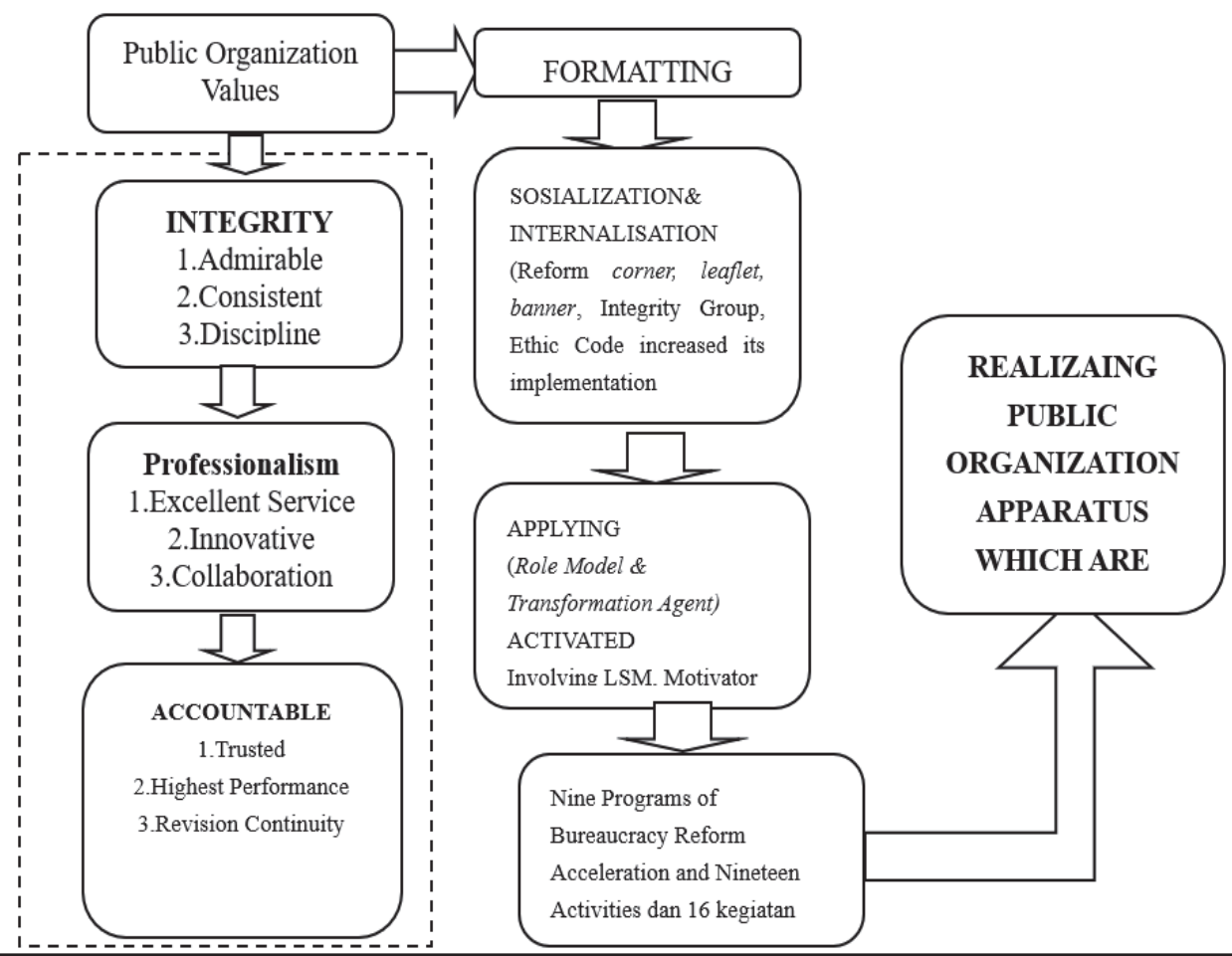

1. IPA values in future conformed by external development and government program then, every five years of government era always delivering new program;

2. Researcher find there is nineteen activities in this research, surely in the next research will be more activities that found. Because it has been issue a regulation law of bureaucracy reform pillar: Regulation Law Number 39 in 2008; Regulation Law Number 25 in 2009; Regulation Law Number 5 in 2014; and Regulation Law Number 30 in 2014.

Figure 3. Organization Intelligence Model and Bureaucracy Reform at Public Organization (Recommendation) Source: Performance of Accountabilities Report in 2013 (adapting) and research result. 
Minor Proposition 7: Organization Intelligence Model is a systematical pattern relates to values and belief agreed (the shared value and beliefs) learnt, applied continuity that become main characteristic about rising process and formatting (for future will be adjusted bases on government advantaging), socialization advantaging, internalization activating and IPA values applying into nine programs of bureaucracy reform acceleration and nineteen activities will realize public organization apparatus which is integrity, professional and accountable.

3.3 The Stimulating Aspects and Obstacle of Organization Intelligence into Nine Programs of Bureaucracy Reform Acceleration at Public Organization

\subsubsection{Stimulating Aspects of Organization Intelligence}

a. At this stimulating factors in this research classifies onto professionalism phenomenon dimension, namely a leader commitment of the highest organization, realized into nine programs policies of bureaucracy reform acceleration values that become a doctrine to all human resource in implementing their performance;

b. Researcher describes that an organization will transform to the better ways which meant its performance is more increase if stimulated factors as follows:

First, the leader commitment comes from the highest position at a public organization.

Leader will obtain a power from their self aimed to be born transformation agent, if leader has these fourth important things namely:

1) Leader as a transformation agent has to have belief that they are able to be activator currently motivator of problem solving faced;

2) Leader as transformation agent always gives away model for their staff or employee;

3) Leader as transformation agent also work totally than their staff or employee; and

4) Leader orients to transformation consistently implementing all of good things.

Second, policy and transformation applying start from supporting the new intelligence norms

1) Through this research policy classifies into professionalism dimension (one of organization intelligence dimension) become a supporting aspect of nine programs of bureaucracy reform acceleration that will support realization public organization apparatus which is integrity, professional and accountable;

2) Direct policy, these will be realized into various rules technically operating able to be applied directly or implemented into activity or daily task;

3) Indirect policy, this is substantial or explanation material is still macro which contain regulation law, there are fourth pillars regulation laws of bureaucracy reform as follows: a) Regulation Law Number 39 in 2008 about State Ministry and its various implementation; b) Regulation Law Number 25 in 2009 about Public Service and its implementation rules; c) Regulation Law Number 5 in 2014 about Civil State Apparatus and d) Regulation Law Number 30 in 2014 about Government Administration.

4) Policy technically support new intelligence norm relates to benefit guidance in behavior transformation such as: a) Management System Manual of Human Resources Integrated Basically Competence; b) Information system application of human resource management integrate competency basis; c) Agent training as role model followed by all dignitaries and staff; d) Integrity group training followed by them; and e) Behavior guidance of them.

5) The new intelligence norm realized into dignitaries and staff act, these are able to be implemented activity as various policies realization, both of regulation law rules basically of nine programs implementation of bureaucracy reform acceleration that able to realize public organization apparatus which is integrity, professional and accountable.

Third, values and new behavior have been supporting new act.

Concerning three criterions of theories stated above, that are an organization successful will be transform if the values and new behavior have been supporting newest act.

1) Beginning bureaucracy reform arranged at one of public organization hasn't arranged or formatted main values agreed together as dignitary guidance and staff in working. Since rolled nine programs of bureaucracy reform acceleration arranged values that are Integrity, Professional and Accountable supported by rules about ethic code staff.

This rule contains of value obligate to be perceived and accomplished by all staff in priority good behavior, discipline, self dedication, competence, able to complete task on time, and liable to task bases on process field 
also the better result. These values believed able to create cleanness staff, competence and service, or meant will create public organization apparatus which is integrity, professional and accountable.

2) Values and behavior, act intended has been improved onto dignitary act and staff at public organization area, for example: doesn't smoke at working place, putting on identity card, doesn't energize mobile phone in an office, doesn't use office facility for private, doesn't receive a gift from guest visiting on, doesn't implement fictive consignment, and refuse to sign fictive SPPD from other institution;

3) Behavior addressed, suitable with research result onto IPA value applying quantitatively and qualitatively improve advantaging bases on survey done by independent institution, such as respondent perception onto Integrity values stated that: "about integrity I'm not doubt, that means it has improved the better progress than in 2010, previously able to consign absence because there is a lot of staff looking for side job outside".

Minor Proposition 8: The highest leader commitment or an organization, policy and transformation applying value support new intelligence norms, values and new behavior that have appeared and support new behavior, creating supporting aspect realizes public organization apparatus which is integrity, professional and accountable

\subsubsection{An Obstacle Aspect of Organization Intelligence}

Researcher describes that besides found supporting aspect also an obstacle aspect of organization intelligence.

1) An obstacle aspect addressed into organization intelligence includes four dimensions of this namely professionalism, society orientation, performance orientation and staff prosperity orientation, where these belief and devotion dimensions become basic of theses other dimensions onto nine programs of bureaucracy reform acceleration;

2) There are seven obstacles aspects onto organization intelligence reflect onto four dimensions of organization intelligence in this research. these are classified as follows:

First, professional dimension reflect into staff capacity aspect hasn't been maximal that constitute of human resource development;

Second, professional dimension reflect into structure arrangement aspect hasn't been suitable with liability;

Third, performance orientation dimension reflect into e-government development aspect hasn't been optimal;

Fourth, performance orientation dimension reflect into inefficient aspect of civil servant facility and infrastructure utilizing;

Fifth, society orientation dimension reflect into quality service increasing for public is insufficient;

Sixth, Society orientation dimension reflect into hasn't optimal aspect into transpiration advantaging and accountability; and

Seventh, staff prosperity orientation dimension reflect into hasn't optimal of civil servant prosperity advantaging.

Base on these seven obstacles aspects are reflecting from these four dimensions of organization intelligence by amount activities as many as 25 , bases on theory to minimize or reduce obstacle addressed need an increasing highest leader commitment that is realized by adapting policy and practice value transformation in order will be supporting new act appearance.

Minor Proposition 9: The overcome twenty five activities into four dimensions of organization intelligence classify into professional, societies orientation, performance orientation and staff prosperity orientation, where belief and devotion basically from these other four dimensions while an obstacle aspect will be faced by highest leader commitment, conforming policy, practice value transformation, and new behavior will accelerate the realization of public organization apparatus which is integrity, professional and accountable.

Base on these three factors in this explanation consists of: 1) Organization intelligence focusing; 2) Organization intelligence model focusing; and 3) supporting aspects focusing so is obstacle aspect, these factors are related to bureaucracy reform technically developed into nine programs of bureaucracy reform acceleration that able to be classified as follows:

First focusing, organization intelligence into nine programs of bureaucracy reform acceleration at public organization as conveyed above, there are five dimensions or organization intelligence, where belief and devotion dimensions basically into other four dimensions namely Professionalism, Societies Orientation, Performance Orientation, and Staff Prosperity Orientation, this research found nineteen activities "accelerating" of nine programs of bureaucracy reform acceleration.

Second focusing, organization intelligence model into nine programs of bureaucracy reform acceleration at 
public organization

This model today (existing) as systematical pattern relates to values and belief agreed (the shared value and beliefs) learnt, applied continuity basically of main characteristic about rising process, formatting, socialization, internalization and applying Integrity values, Professional, and Accountable into nine programs of bureaucracy reform acceleration will realize public organization apparatus which is integrity, professional and accountable.

This model is suggested systematically pattern relates to values and belief agreed (the shared value and beliefs) which is learnt, applied continuity becoming main characteristic about rising process, formatting, (for future will be matched with government development), socialization increasing, internalization activating and IPA values applying into nine programs of bureaucracy reform acceleration and nineteen activities will realize public organization apparatus which is integrity, professional and accountable. Into organization intelligence model suggested it, an excellent intelligence values appeared and created need to be observed once by determining government advantaging, socialization and internalization need to be increased. While in applying need to be activated once by concerning Public Interest Group, motivator and ESQ internally field at public organization, excellent intelligence values consist of Integrity, Professional, and Accountable, these are core values.

Third focusing, supporting and obstacle aspects of nine programs of bureaucracy reform acceleration. Through this research there is three process of transformation quantifying of organization intelligence basically become supporting aspect namely: 1) The highest leader organization commitment; 2) Policy and practice of supporting transformation value of new norm intelligence; and 3) Values and new act have started supporting new act. If organization intelligence becomes supporting aspect addressed always be increased and related to nine programs of bureaucracy reform acceleration will accelerate public organization realization which is integrity, professional and accountable.

The obstacle aspects of organization intelligence found twenty five activities into four dimensions (professional, society orientation, performance orientation and staff prosperity orientation) that its implementation isn't optimal. These if it consists of these twenty five activities can be done by the advantaging of highest leader commitment realized through policy adapting and value transformation practice in order able to stimulate new act, and will accelerate realization of public organization apparatus which is integrity, professional and accountable.

Bases on this finding, arranged from minor proposition 1 to minor proposition 9, then arranged into one mayor proposition as follows:

Mayor Proposition: Organization intelligence dimension called as belief and devotion, professionalism, society orientation, performance orientation and staff prosperity orientation, where belief and devotion basically on the fourth other dimensions into nine programs or bureaucracy reform acceleration supported by nineteen activities, by continuity of socialization advantaging, internalization and activating implementation of an excellent IPA intelligence values, increasing proponent aspect together with overcoming these twenty five obstacles aspects that will realize acceleration of public organization apparatus which is integrity, professional and accountable. 


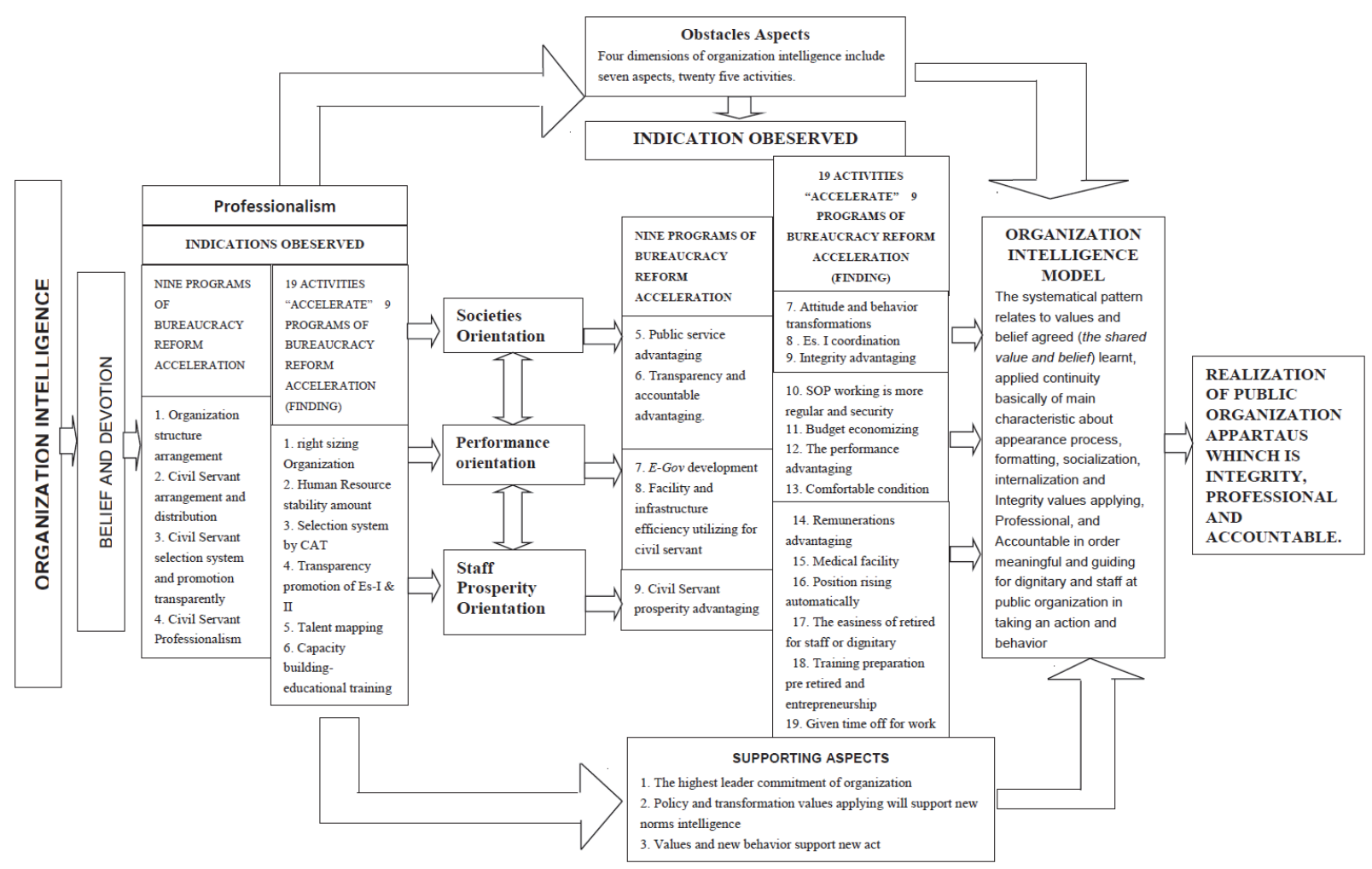

Figure 4. Scetch of Nine Programs of Bureaucracy Reform Acceleration Development

Sources: Sembiring, Wibowo, Robbins, Jerome Want and one of public organization.

\section{Conslusion}

First, these four dimensions of organization intelligence dimension (professionalism, society orientation, performance orientation, and staff prosperity orientation), belief and devotion dimensions basically of these fourth other dimensions which has been implemented nine programs of bureaucracy reform acceleration, it has been found on the nine teen activities of "acceleration" of nine programs of bureaucracy reform acceleration, as follows:

a. Professionalism dimension are reflecting these four of nine programs of bureaucracy reform acceleration (organization structure arrangement, quantify arrangement and civil servant distribution, selection system of civil servant candidate and it promotion openly and their professionalism) found six activities namely: right sizing organization, human resource stable quantify, selection system by applying Computer Assist Test system, openness promotions of Echelon I and Echelon II, Talent mapping, and Capacity building together with educational training.

b. Society orientation dimension are these two reflection of nine programs of bureaucracy reform acceleration (public service and transparency so is accountable advantaging) found three activities namely attitude and behavior transformations, coordination among deputy and integrity advantaging.

c. Performance orientation dimension is reflecting these two of nine programs of bureaucracy reform acceleration (E-Gov advantaging and the efficiency of facility and infrastructure utilizing for civil servant) found four activities namely Standard Operating Procedure work is more regular, on time, budget economizing, the rising performance and comfortable;

d. Staff prosperity orientation dimension is reflecting of increasing civil servant prosperity found six activities namely remuneration rising, medical clinic facility, position rising automatically without other requirement, the easiness way of dignitaries or staff retired, training program approaching retired period and entrepreneur, given time off from work;

e. Professionalism dimension basically of these third society orientation dimension, performance and staff prosperity orientations. Because professionalism into human resource is more determined into nine programs of bureaucracy reform acceleration; 
Second, organization intelligence model has systematically pattern relates to values and belief agreed (the shared value and beliefs) learnt, applied continuity of main characteristic about appearance process, formatting, socialization, internalization and Integrity values applying, Professional, and Accountable while giving benefit and guidance for dignitary or staff at public organization in taking an actions.

The IPA values applying, especially at Integrity values is better than before in 2010, in past we able to consign absent because there are many staff looking for side job outside. At Professional values relates to cooperation and knowledge sharing has been worked well, because of agent of change existence, Internal Bureaucracy Reform and corner reform forums. Accountabilities values generally has been changing staff arrangement, which means for a rapidly changing given appreciate likes scholarship reward, joined into certain educational training, or position rising, while for refused or doesn't change will be given punishment.

Third, one of supporting aspect of bureaucracy reform successful at a public organization is fully support from leader both of highest and middle leaders. Because this research relates to organization intelligence and bureaucracy reform meaningful of intelligence values (core values) realized into attitude and behavior, it is supported by the highest leader commitment into nine programs of bureaucracy reform acceleration, this commitment realized into attitude and behavior and realized by various policies resulted. There is not only found supporting aspect but also twenty five obstacles aspects in this research: professionalism dimension into 15 activities, society orientation dimension consist of 4 activities; performance orientation dimension consist of 4 activities; and staff prosperities dimension consist of 2 activities. Attitude and behavior transformations need a long time, but it is implemented nine programs of bureaucracy reform acceleration at public organization has been stimulating them realized into five dimensions of organization intelligence (belief and devotion dimensions basically of other four dimensions) at each program addressed. These are because of the highest leader commitment, but it need to be followed by middle and low level commitments. These are needed because staff needs a guidance and role model from their leader in order activities charged to them completed on time and a target.

\section{Suggestion}

Bases on the conclusion presented in this research entitled "ORGANIZATION INTELLIGENCE AND BUREAUCRACY REFORM AT PUBLIC ORGANIZATION, researcher suggest:

First, There are nineteen activities include it as following up nine programs of bureaucracy reform acceleration, these all are reflecting four dimensions of organization intelligence, each dimension based on belief and devotion, aimed to accelerate public organization apparatus acceleration which is integrity, professional and accountable, while need to be enlarged activities as following up both of internal survey result or done by independent institution.

Second, Activity as following up of nine programs of bureaucracy reform acceleration addressed to focusing on professionalism dimension, because it is more determining into bureaucracy reform accelerations and one of these nine programs include civil servant professionalism program.

Third, Need to be arranged new policy classifies into rules or another, for example relates to position rising automatically without attached another requirements, openness promotion of Echelon I and Echelon II, technical educational training, internal rotation.

Fourth, Organization intelligence model at public organization, in this socialization and internalization steps need to be more increased its implementation such as through various activities reform corner, leaflet, banner, integrities group, ethic code. In this reform corner not only discuss various activities at each unit, but also implemented to reduce a communication obstacle among staffs and dignitary.

In this implementation level of IPA values need to be activated. Through transformation agent training and role model, because there are various dignitaries and staffs have been retired, promotion or mutation to another institution. This implementation utilized as basic attitude and behavior both of dignitaries or staff to implement task relate to nineteen activities into nine programs of reform acceleration. By this organization intelligence model suggested will accelerate the realization of public organization apparatus which is integrity, professional and accountable.

Fifth, An excellence intelligence values are Integrity, Professional and accountable need to be observed, because every the leader or government alteration into five years new period has different vision and mission, but for bureaucracy reform is still continue implemented and revised because of societies petition continuously.

Sixth, supporting aspect and organization intelligence obstacle in this research reflects on these four dimensions or organization intelligence. This is explaining about values, attitude and behavior transformation. In realization 
of these don't take an easy way and needed a long time, so that deed the increasing of highest and middle leader commitment that is realized into their daily actions.

Seventh, one of commitment realization addressed a policy relates to bureaucracy reform. It has been issued policy includes regulation law rule, starting from regulation law that is classified into four regulations law as bureaucracy reform pillar, government rule, grand design of bureaucracy reform, president regulation, another tens of rule. Policy as a following up from these fourth regulations law as bureaucracy reform pillar, as soon as issued policy deviation, start from government, president, and ministry rules. If it has been issued policy until ministry rule consistently implementing, and the most important is policy addressed doesn't change away, because stakeholder from this policy not only come from ministry or institution but also until government province otherwise district or city governments.

Eight, for the next research relates to organization intelligence, bureaucracy reform and nine programs of bureaucracy reform acceleration at public organization are livelier and more intensive, because researcher has limited knowledge, outlook and time.

\section{References}

Albrow, M. (1996). Bureaucracy, Translate by M. Rusli Karim, Tiara Wacana, Yogakarta.

Basuki, J. (2006). Organization Intelligence Concept and Practical, Yayasan Pembinaan Manajemen, Jakarta.

Caiden, G. E. (1991). Administrative Reform Comes of Age, Waler de Gruyter, Berlin, New York, 1991.

Denhardt, J. V., \& Robert, B. D. (2003). The New Public Service: Serving, Not Steering, Armong NY: M.E. Sharpe.

Eko, P. (2013). Leader and Bureaucracy Reform, Inspire Notice and Leadership Measurement into Bureaucracy Reform Implementation, Kementerian PANRB and GIZ.

Ismiyarto (2005). Organization Intelligence in the Context of Public Service Quality at the Office of Integrating Service in Sragen District (Thesis), 2005.

Ismiyarto (2015). Organization Culture, Motivation, Job Satisfaction and Performance of Employees towards the Implementation of Internal Bureaucracy Reform in the Ministry for the Empowerments of State Apparatus and Bureaucracy Reform (The Ministry of PANRB), 5(1), 2015.

Ismiyarto (2016). Organization Intelligence Study in the Program of Bureaucracy Reform Acceleration at Ministry of State for Administrative and Bureaucratic Reform Apparatus (Kementrian PANRB) (Dissertation).

Keban, Y. T. (2008). Six Dimensions Strategy of Public Administration Concept, Theory and Issue, Gava Media, Yogyakarta.

Keban, Y. T. (2010). Capacity Development Issue and Good Governance into Bureaucracy Reform, into State Apparatus Reform Book looked out, Yogyakarta, Gava Media.

Lepawsky, A. (1965). Administration, Oxford \& IBH Publishing Co, First Indian Edition, 1965.

Ministry of State for Administrative and Bureaucratic Reform Apparatus Planning Bureau, Policy Arrangement Material of Bunga Rampai, State Administrative Apparatus Field, Jakarta 2012.

Ministry of State for Administrative and Bureaucratic Reform Apparatus, Strategy Planning of Ministry of State for Administrative and Bureaucratic Reform Apparatus in 2010-2014, Jakarta 2012.

Mustafa, D. (2013). Government Bureaucracy, Alfabeta, Bandung.

Prasojo, E. (2014). Bureaucracy Reform into Government System Realization and Justifying Developing (presentation material), Jakarta.

Sailiwa, W. S. (2012). The Advantaging of State Apparatus Performance through Management System Arrangement of Civil Servant into National Competition Advantaging. State Apparatus Performance Journal Volume II in 2012.

Siagian, S. P. (1996). Bureaucracy Pathology, Bumi Aksara, 1996.

Siagian, S. P. (2000). Development Administration, Dimension Concept and its Strategy, Jakarta, Bumi Aksara.

Sinambela, L. P. D. (2007). Public Service Reform, Theory, Policy, and Implementation, Bumi Aksara, Jakarta.

Thoha, M. (1991). Bureaucracy Act Perspective: State Administration Dimension Volume II, Jakarta. 
Thoha, M. (2009). Government Bureaucracy of Indonesia Reform Era, Kencana, Jakarta.

Thoha, M. (2010). Public Administration Contemporary Science, Kencana, Jakarta.

Wibowo, (2007). Management Transformation, Raja Grafindo Persada, Jakarta, 2007.

Wibowo, (2013). Organization Intelligence an Action into Organization, Raja Grafindo Persada, Jakarta 2013.

Zauhar, S. (2001). Administration Reform, Bumi Aksara, Jakarta, 2001.

\section{Regulations Law:}

Regulation Law Number 39 in 2008 about State Ministry.

Regulation Law Number 25 in 2009 about Public Service.

Regulation Law Number 5 in 2014 about Civil Servant Apparatus.

Regulation Law Number 30 in 2014 about Government Administration.

\section{Copyrights}

Copyright for this article is retained by the author(s), with first publication rights granted to the journal.

This is an open-access article distributed under the terms and conditions of the Creative Commons Attribution license (http://creativecommons.org/licenses/by/4.0/). 